\title{
CONFLICTING MODELS OF AUTHORITY AND EXPERTISE IN FRONTINUS' STRATEGEMATA ${ }^{1}$
}

Alice König

TO ALL

\author{
MILITARY SOULS \\ OF THE
}

\section{English NATION}

Tis for your Perusal that this Treatise is publish'd... if the English Courage alone, without the Assistance of Art, hath been so Victorious, what Wonders would it not be able to perform, if it were seconded by Policy and Craft? I conceive therefore it may not be useless to you, my Brave Countrymen, to have an Abstract, or a Collection in your own Language of the Stratagems which have been practiced in War by the most experienced Commanders... For that purpose I have Translated FRONTINUS, who, being a ROMAN Warriour, and of the Order of the Consuls, Collected the most remarkable Stratagems of the PERSIANS, GREEKS, ROMANS and CARTHAGINIANS.

Marius d'Assigny, The Stratagems of War, or, A collection of the most celebrated practices and wise sayings of the great generals in former ages written by Sextus Julius Frontinus, one of the Roman consuls; now English'd

For more than sixteen centuries, from the late first century AD down to the end of the renaissance and beyond, Frontinus was regularly referred to as an expert and authority on military matters. The twelfth-century scholar John of Salisbury, for instance, drew on Frontinus' writing as much as he did on the works of Virgil, Plato and a host of other classical authors in his formulation of a new political philosophy in the Policraticus. ${ }^{2}$ Excerpts of Frontinus' Strategemata turn up in mediaeval crusading manuals, such as Marino Sanudo Torsello's Book of the Secrets of the Faithful of the Cross. In 1417 one Jean Gerson, tutor to the then Dauphin of France, lists the Strategemata alongside the Bible, other Christian texts, and works by Aristotle, Sallust, Livy, Valerius Maximus, Seneca, Vegetius and Augustine (inter alia), as a kind of literary 'Ark of the Covenant' that the young prince should absorb and carry metaphorically about with him 'through the desert of this world'. ${ }^{3}$ Christine de Pizan (a scholar well known to Gerson, who also proffered advice to those in power in fourteenth- and fifteenth-century France) quotes extensively from the Strategemata throughout the second part of her Book of Deeds of Arms and Chivalry. Although Machiavelli never mentions Frontinus by name, he too seems to have borrowed from the Strategemata in more than one of his works. ${ }^{5}$ And translations of the text abounded across Europe, including one addressed to Henry VIII, which promised to

\footnotetext{
${ }^{1}$ I am grateful to The Leverhulme Trust for the Research Fellowship during which this article was written; also to Jason König, for his incisive feedback and advice.

${ }^{2}$ Martin 1997; cf. Nederman 1990: xx.

${ }^{3}$ Gerson, Au précepteur du Dauphin, Constance, vers Juin 1417 (Glorieux 1960: 20315; cf. Thomas 1930: 30-55, who dates the letter rather to 1408-10; also MazourMatusevich \& Bejczy 2007).

${ }^{4}$ Willard 1995; Forhan 2002: 150-7; le Saux 2004.

${ }^{5}$ In particular, in his Art of War (Lynch 2003: xiv-xv); see also Wood 1967, on the possibility that Frontinus' Strategemata influenced Machiavelli's didactic method in his Discourses on Livy.
} 
support that 'moste high, excellente, and myghtye Prynce' by inspiring and instructing his military captains (who 'have oft declared that they lytell nede any instructions, any bokes'), just as the Strategemata claimed to inspire and instruct its original readers. ${ }^{6}$

This chapter is about the models of authority and expertise that the Strategemata itself projects and prompts reflection on. But it is instructive to begin by looking at what it was about the text (and its author) that prompted later readers to deem it authoritative; not only because some of them continue to shape our approaches to the Strategemata today, but also because the differences between their responses to it point up some fascinating contradictions and tensions within the treatise - tensions which are revealing of the challenges and opportunities that many scientific/technical/didactic authors have wrestled with in constructing and parading authority and expertise, especially in the military sphere.

It was arguably Vegetius, writing in the late fourth- or early fifth-century AD, who cemented Frontinus' status as an authority on military matters by citing him as one of his most important sources (at Epitome 1.8 and 2.3). ${ }^{7}$ Vegetius builds his own authority and expertise on scholarly foundations, and presents himself as writing within an established and important literary tradition: one (he claims) that had begun in ancient Greece but had been honed and was now dominated by Roman writers, who had helped to transform military practice into a scientific discipline. ${ }^{8}$ Cato the Elder is identified not just as an early example but as a forthright champion of this tradition:

'Cato, because he was invincible in battle and had often led the army as consul, believed that he could benefit the republic further by setting down in writing his military learning. For things that are done bravely last one generation; but things that are written down for the genuine benefit of the republic last forever.' (Epitome 2.3)

Frontinus is then singled out as following in Cato's footsteps: 'Several others did the same, but in particular Frontinus, whose industry in this regard was approved by Trajan.' Frontinus, like Cato, had not just written about soldiering but had seen plenty of military service himself; he had also served as consul no fewer than three times, and was doubtless 'approved' by Trajan far more for the role he played in securing Nerva's adoption of Trajan as his heir than for anything that he wrote. ${ }^{9}$ Nonetheless, Vegetius' overriding interest in the written word leads him to suggest that what makes Frontinus a significant figure in military history (someone worth citing and connecting oneself with) is his literary activity, not his practical experience. For Vegetius, Frontinus is authoritative (and was so for his contemporaries) above all because he was a Roman author writing in (and able to link Vegetius to) a long line of earlier authors who together had refined and disciplined military knowledge.

Aelianus Tacticus, writing much closer in time to Frontinus but from a Greek perspective, offers a different analysis. The prologue to his Tactical Theory stages a stand-off between Greek military 'science' (mathema and theoria) and contemporary Roman military practice (dunamis and empeiria). Inspired by the former but

\footnotetext{
${ }^{6}$ Morysine 1593.

${ }^{7}$ On the relationship between Vegetius and Frontinus' survival, see esp. Allmand 2009; also Allmand 2011: 48-61; Lenoir 1996: 81.

${ }^{8}$ See esp. the prologues to Books 1 and 3 and 1.8 , where the act of writing is associated with the development of military knowledge; also Formisano in this volume on the authority of literature/writing (as opposed to practical experience) in Vegetius' Epitome and other military manuals; and Formisano 2009: 333-5 on Vegetius' role in making the 'art of war' a fundamentally literary phenomenon.

${ }^{9}$ On Frontinus' career: Eck 1982: 47-52; Rodgers 2004: 1-5.
} 
(supposedly) daunted by the momentum of the latter (which was achieving unparalleled successes under the aegis of Aelian's dedicatee, Trajan), Aelian claims that he initially hesitated to write about 'a science forgotten and moreover long out of use since the introduction of the [Roman] system'; ${ }^{10}$ until, that is, an encounter with Frontinus, whose own interest in Greek military theory encouraged Aelian to proceed: '...I was able to spend some days at Formiae with the distinguished consular Frontinus, a man of great reputation by virtue of his experience (empeiria) in war. Discovering in conversation with him that he had no lesser regard for Greek tactical science, I began not to despise their tactical writing, thinking that Frontinus would not pay so much attention to it if he indeed considered Roman tactical usage superior.' (Tact. pr. 3) Later on (Tact. 1.2), Aelian identifies Frontinus explicitly as an author (as he asserts the literary and scholarly foundations of his own expertise). Indeed, Frontinus stands out as the only Roman in a list of notable military writers whose works Aelian has read; and it is possible that the very format of his Tactical Theory was influenced by the Strategemata. ${ }^{11}$ It is significant, however, that in the story of their meeting it is Frontinus' consular status and his practical experience that Aelian chooses to highlight. His literary activities are implicit in the background, but the hands-on connotation of the word empeiria identifies Frontinus' campaigns in Britain and elsewhere as the foundation of his authority and expertise and the main reason why his views on military matters (and Aelian's literary project) might carry some weight. Frontinus' endorsement of Aelian's Tactical Theory is not authoritative because he is a leading light in a long scholarly tradition. Indeed, as flattering as his inclusion in that list of Aelian's sources might look, it serves primarily to point up the overwhelming dominance of Greek learning on the subject and to undermine Rome's contribution. ${ }^{12}$ Rather, Frontinus' supposed support of Aelian is meaningful because of his political prominence and connections; and also (especially) because Frontinus can serve as an embodiment of the contemporary Roman military practice/prowess that Aelian's Greek 'science' is trying to compete with.

In the preface to his edition of the Strategemata quoted above, Marius d'Assigny identifies Frontinus both as an author (whose text has much to teach the valiant English about the 'art' of war) and as a 'warrior' and consul. He is ROMAN, and the authority of the Classical past is one of the things that makes him worth reading; d'Assigny, like Vegetius, turns to Frontinus in part because he hails from the height of the Roman empire. But it is also the access that he gives to other historical figures, PERSIANS, GREEKS, ROMANS and CARTHAGINIANS, that attracts d'Assigny. For him, the authority of the Strategemata lies as much, if not more, in the expertise of the 'experienced commanders' whose 'remarkable stratagems' Frontinus has collated. The author's scholarly, political and military credentials count for something; but readers will learn even more from the characters who inhabit the text and whose deeds Frontinus (and now d'Assigny) has helped to immortalise. Indeed, they will learn from others too: for d'Assigny appends to his translation of the Strategemata 'A Collection of the Brave Exploits and Subtil Stratagems of several famous Generals since the Roman Empire' and, to follow that, 'A Discourse of Engines used in War'. Like de Pizan, among others, he not only 'Englishes' FRONTINUS, in other words; he updates him, leaning on his various layers of

\footnotetext{
${ }^{10}$ This and the following translation are from Devine 1989.

${ }^{11}$ For instance, commentators often see Aelian's use of sub-headings as his own innovation (Devine 1989: 32; Stadter 1978: 118), but he may have been copying Frontinus in this.

${ }^{12}$ In fact Frontinus is characterised there (somewhat unjustly) as a commentator on other writers, not a theorist in his own right.
} 
authority to generate some of his own, but also alerting us to its limits - to the fact that Frontinus (like d'Assigny himself) does not have a monopoly on military knowhow but is one step in an on-going process of pooling and re-circulating many people's (different forms of) expertise.

The story of the Strategemata's reception is much longer and wider-ranging than that; but these three episodes offer a taste of the variety of responses to and uses made of the text by later readers. Between them (and this is why they were chosen) they also expose the multiplicity of axes along which authority and expertise are constructed - or at least explored - in the Strategemata itself. For as this chapter will show, textual and scholarly authority share the stage with hands-on experience and the native wisdom of men from days gone by. That combination is not uncommon; indeed, it is evident in several of the other texts discussed in this volume. However, this chapter will argue that in Frontinus' Strategemata scholarly learning and practical know-how end up in tension more than in partnership with each other in particularly thought-provoking ways.

\section{TEXTUAL AUTHORITY AND ‘SCIENTIFIC’ EXPERTISE}

The first kind of authority that Frontinus lays claims to at the start of the Strategemata is of the scholarly, textual, 'scientific' variety. By way of introduction, he reminds us of the existence of his (now lost) De Re Militari, which (he claims) is what inspired the present text:

'Since I, alone amongst those studying it, have attempted to draw up (instruendam) a science (scientia) of military matters, and since I seem to have achieved my objective, as far as my efforts could manage, I feel that the project I have begun still requires me to collect together in a serviceable handbook (expeditis amplectar commentariis) the clever deeds of generals (sollertia ducum facta) which the Greeks have gathered together under the one name 'strategemata'.

His industry, which borders on perfectionism, is impressive, but on its own does not render him particularly authoritative. ${ }^{13}$ More significant is the systematisation of material implicit in his use of instruo and scientia: for these set Frontinus up not merely as a conveyor but as a refiner of knowledge, a theorist even. In addition, his suggestion that he is one of the first to discipline military know-how thus (despite being a stock and highly debatable claim) stamps his mastery over it yet more forcefully. ${ }^{14}$ By dint of his earlier writing, and the proclaimed originality of the 'scientific' approach that underpins it (which itself taps into a wider trend of systematisation of knowledge that had long been associated with authority and expertise), Frontinus figures at the start of the Strategemata as a - if not the contemporary expert on military matters.

In alerting us to his own achievements as an author, he also positions himself vis-à-vis other literary and scholarly authorities. His use of Greek terminology to explain what he means by sollertia ducum facta, for instance, invokes a strand of the Greek military writing tradition and identifies the Strategemata as a descendent of it. $^{15}$ But it perhaps also invokes a Roman tradition too, that of supplanting Greek

${ }^{13}$ Although, as Wietzke in this volume argues, industry itself - particularly in a work that could be said to benefit the community (Strat. 1 pr.3) - confers a degree of social authority on the author.

${ }^{14}$ Wheeler 1988: 19-20; Santini 1992: 984-5; Lenoir 1996: 82.

${ }^{15} \mathrm{Cf}$. Valerius Maximus 7.4, whose suggestion that there is no equivalent Latin term for strategemata also implies that 'stratagems' (or at least writing about them) are 
models with new Roman equivalents. Frontinus' sentence structure here surrounds the

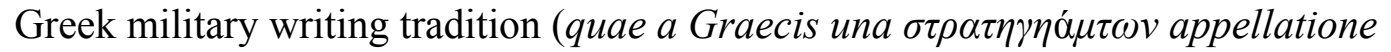
comprehensa sunt) with his (very Roman) new version of it (sollertia ducum facta... expeditis amplectar commentariis ${ }^{16}$ ), hinting - not least through the suggestive military metaphors lurking in expeditis and amplectar - at the possibility that he is not merely adopting a Greek model but besieging and taking it over.

The historiographic tradition is another co-ordinate that Frontinus uses to characterise his Strategemata and assert its authority. He points out overlaps (from which his own text derives some associated validity and status): instructive exempla can be found in many historical texts. Indeed, much of the material in his treatise has already been recorded elsewhere:

'I neither ignore nor deny the fact that in the course of their works

historians have also included this feature, and that all significant examples have already been set down by writers in one way or another (et $a b$ auctoribus exemplorum quidquid insigne aliquot modo fuit traditum).'

(Strat. 1, pr. 2)

The juxtaposition here of ab auctoribus and exemplorum indicates that as well as historians Frontinus is keen to connect his work with a specific off-shoot of historiography, the exempla tradition. In fact, an observant reader will notice that what he goes on to say - about what distinguishes his Strategemata from these other texts - invites particular comparison with Rome's most famous exponent of that genre, Valerius Maximus. For, when Frontinus claims that his Strategemata will spare readers the tedious task of sifting through the vast body of historical writing to look for scattered examples themselves, he is echoing Valerius Maximus' own prefatory remarks. ${ }^{17}$ Frontinus goes on to assert the Strategemata's superiority over even Valerius' kind of writing, however; for he argues that authors of exempla collections, no less than historians, still 'confound' the reader with the volume of their material, despite the fact that they are in the business of excerpting from histories ('those, too, who have made selections of notable examples have overwhelmed the reader with, as it were, a great heap of information.'). He thus highlights links between his treatise and other well-established genres, and derives some associated authority from them (and the overlaps that he points to between his writing, historiography, and so on, serve as a useful reminder that distinctions between 'technical' and other kinds of text/genre were not nearly so clear-cut in antiquity as many studies suggest). However, he also claims to stand out from them, to offer his readers something different.

Systematisation comes to the fore again as Frontinus explains what it is that sets his Strategemata apart. Rather than far-flung anecdotes or an overwhelming mass of material (the imagery here makes quite an impression), he promises a collection of examples that has been organised, fittingly, with military precision:

'My effort centres around the challenge of setting out precisely whichever example is required, in any given circumstance, as if in response to questions. For, having surveyed the categories, I have prepared a set of suitable examples as one might prepare a plan of campaign. Moreover, so that they might be divided up and organised according to the variety of their subject-matter, I have separated them into three different books: in the first are examples that relate to pre-battle activities; in the second, those that pertain to the battle itself and to the resolution of conflict; the

originally a Greek tradition; also Wheeler 1988: 25-49 on the Greek history of the genre.

${ }_{16}$ The commentarius is a particularly Latin genre, of course.

${ }^{17}$ Comments that Frontinus makes later in the preface (Strat.1.pr.3) on the theme of not being exhaustive are also reminiscent of Valerius Maximus' preface. 
third will contain 'stratagems' for the formation and breaking of sieges.'

(Strat. 1, pr. 2)

The very military-ness of this layout and Frontinus' authorial approach lends both text and writer an air of martial expertise; indeed, the military metaphors that he uses to describe the Strategemata's organisation perhaps hint at his personal talent for or experience of command. But (as in the case of the De Re Militari) it is also the text's methodical discipline, the systematic nature of its composition, that generates authority $-\mathrm{a}$ feature which subsequent prefaces flag up, and which is reinforced too in the lists of business-like section headings that begin each book and take us step by step through every stage of battle by directing us to the relevant set of anecdotes for each one. ${ }^{18}$ In comparison with the texts and literary traditions on which the Strategemata has drawn, Frontinus' authorship seems (or is meant to seem) not only considerate to his readers but impressively rigorous.

This returns us to the image of Frontinus as a cutting-edge author that the preface began with. And if we wanted further proof that he is keen to establish himself as a big name in the world of military writing, we have only to turn to the start of the text proper, where Cato the Elder pops up as Frontinus' first exemplum (Strat 1.1.1). We meet him in action, in his capacity as one of Rome's most successful commanders; but he is also writing - albeit letters, designed to outwit any Spanish rebels, and not the texts for which Vegetius would later revere him. Nonetheless, his presence heading up the very first section of the Strategemata (leading us into battle as it were, if we want to pursue the text's penchant for military metaphors) is significant. It signals to his readers that Frontinus knows what he is doing (who else should a Roman military writer worth his salt start with?), and that his text takes its inspiration first and foremost from the man credited with establishing Rome's military writing tradition. However (as in the case of Frontinus' self-positioning vis-à-vis the Greek strategemata tradition), it may also do more than that; for in returning Cato to the field of battle (rather than explicitly foregrounding his literary achievements, as Vegetius did), Frontinus may be subtly (even subconsciously) suggesting that he is a successor of Cato's whose own writing on tactics could eclipse that of his eminent and learned predecessor.

\section{NON-TEXTUAL AUTHORITY AND UNSCIENTIFIC 'EXPERTISE’}

Cato's characterisation in the opening exemplum of the Strategemata as a (literate) general, a doer not just an author, is interesting also because of the way in which it shifts the text's emphasis from scientific rigour and book-learning (the themes that have dominated the preface - and that are foundational to so many other military treatises' claims to authority) to less scholarly phenomena, such as native intelligence and practical reasoning. In fact, unscientific 'expertise' dominates the bulk of the text. For, having set himself up as an authority in the preface, Frontinus departs the arena and leaves it to the generals who populate each section to provide the instruction. And, far from drawing on any textual tradition, they rely on their wits. For all its literaryscientific foundations, the Strategemata promises its readers illustrations of what commanders have done by 'ingenious resourcefulness' (that is the force of sollertia ducum facta); 'for in this way future commanders will be surrounded by examples of both consilium ('deliberation' or 'judgement') and providentia ('forethought'), and these will nurture their own ability to think up and execute similar deeds...' (Strat. 1, pr. 1).

\footnotetext{
${ }^{18}$ On both the pragmatics and rhetoric of 'tables of content', see esp. Riggsby 2007 (who, alas, overlooks Frontinus' Strategemata in his discussion).
} 
Take the first section of Book 1, which contains illustrations of the ways in which commanders have successfully concealed their plans. Here, as throughout the treatise, each exemplum begins with the name of the commander whose stratagem is being recorded, reinforcing the sense that it is they who are real authorities here, in both a military and a didactic sense. Their dominance of the narrative (as well as kickstarting every exemplum, they are the subject of most of the main verbs) attests to their ascendancy on the field of battle; but it also establishes them not just as the tactical lessons to be learnt (the models to emulate) but as the readers' teachers. They are the figures whose thoughts and voices we get to hear, judging, deciding, coordinating and commanding; Frontinus, by contrast, almost never interjects to offer any commentary of his own (a feature we will come back to). His style of narrative does influence the way in which we react to them, however. For in example after example, we move rapidly from a commander thinking or wanting something to him acting and achieving it - with no reference, usually, to the episode's wider context, or to any historical precedent or future repercussions for that matter. And this brevity and simplicity, the reductive economy with which Frontinus recounts each anecdote, repeatedly presents tactics as a matter of on-the-spot intuition, wisdom and decision.

At Strategemata 1.1.1, for example, we learn that Cato no sooner 'reckoned' (existimabat) that the Spanish cities that he had vanquished might rebel against him than he took steps to prevent them from doing so. ${ }^{19}$ He wrote to each, ordering them to destroy their fortifications, and threatening war unless they obeyed straightaway; and he ordered the letters to be delivered to all the cities on the same day. No details of the wider campaign are provided; we get only this compressed description of Cato's concern and the stratagem that he came up with in response to it. ${ }^{20}$ Combative verbs abound as he switches from thinking to doing; and the brevity of clauses and rapid alternation between Cato's actions (scripsit, minatus, iussit) and the activities that he demands of the Spanish cities and his envoys (diruerent, obtemperassent, reddi) conveys both the speed with which he will respond if his instructions are not quickly obeyed and his decisiveness in penning and dispatching them. The result (apparently) is instant. In reality, the co-ordination of their delivery would have delayed the letters' arrival until those destined for the farthest cities had had time to reach their goal (as Appian pointed out, Hisp. 41). In this account, the letters are no sooner sealed and sent than they are received - and acted upon: 'Each of the cities thought that the order had been for them alone; if they had known that the same message had been sent to all of them, a joint refusal would have been possible.' Thanks to his foresight, and with a few strokes of his pen (and that of Frontinus), Cato has tricked every city in the region into swift capitulation.

And so it goes on. Again and again, over the course of four books, fifty subsections, and nearly five hundred more or less formulaic exempla, commander after commander notices/realises/discovers/believes/fears (animadverto, sentio, intellego, compero, didico, vido, scio, credo, timeo, vereor); he quickly thinks/decides/plans/desires (arbitror, statuo, constituo, peto); and then he acts - and invariably succeeds with immediate effect. Occasionally the protagonists are whole nations ('The Romans', 'The Athenians', 'The Thracians ${ }^{\text {,21 }}$ ) or groups of

\footnotetext{
${ }^{19}$ Existimo is a verb which conveys some of the imprecision of mental reasoning, flagging up Cato's agency in judging, deciding.

${ }^{20}$ Cf. Livy 34.17 and Appian, Hisp. 40-1, where we discover, e.g., the location of the cities in question, and learn more about Cato's motivations.

${ }^{21}$ This is particularly true in a couple of sections of Book 3: e.g., Strat 3.15.1-3 and 5, 3.13.1-2, and 3.18.1-3; also, e.g., 1.3.4; 3.17.1.
} 
commanders ('certain Spartan generals', 'the survivors of the Varian disaster ${ }^{22}$ ); and in Book 4 commanders sometimes collaborate with the Senate or consuls. ${ }^{23}$ For the most part, however, the exempla concern individuals who can take sole credit for their triumphs (at least as Frontinus narrates them). And it is their reasoning, judgement, common sense, use of logic, wisdom, intelligence, cleverness, resourcefulness, inventiveness and cunning that wins the day. As noted above, Frontinus' authorial absence from the main body of the text means that he rarely comments explicitly on a stratagem or a commander; however, the vocabulary that he uses to characterise them in passing - consilium, sententia, prudentia, ratio, calliditas, sollertia - tells a consistent tale.

There are exceptions. In a couple of anecdotes (1.10.1 and 4.7.6) we are told that a commander was prompted towards a particular stratagem by experience (experimentum). Another (2.3.7) employs veteran troops that had been 'long trained' (diu edocto) and were 'practised' (peritus) - one of the few references in the text to training/instruction (of troops, of course, not commanders). A few exempla later (2.3.15), Mark Antony has recourse to a technical manoeuvre (the testudo). These references to experience, training and specialist methods are unusual, however. In the preface to Book 3, Frontinus explicitly rules out discussion of technological operations (and with it, the need for any associated specialist learning) on the grounds that military engineering has nothing to contribute (any longer) to the formulation of stratagems. His commanders rarely base their schemes around set-piece manouevres and typically depart from, rather than follow, conventional practice. And though in one exemplum (2.6.10) the 'hero' (Pyrrhus) is the author not of a cunning deed but of a collection of 'precepts on generalship' (praecepta imperatoria) from which one specific stratagem is drawn, textbooks play no formative part in any of the stories that the Strategemata sets out. ${ }^{24}$ At no point do we ever see a commander reading a military manual - or any kind of commentary, or history, philosophy, or even epic, for that matter (just the odd letter, which invariably outwits them). ${ }^{25}$ Nor do we see one devising a plan by copying a precedent. ${ }^{26}$ Established procedures and principles pop up from time to time (often to be bypassed or adapted); but their input is drowned out by the volume of stories that showcase off-the-cuff, out-of-the-box, non-specialist, 'unscientific' intelligence. As the bulk of the text post-preface presents them, military stratagems - and, by extension, generalship itself - have little to do with learning or indeed teaching; they rely on individual nous.

\section{BETWEEN SOLLERTIA AND SCIENTIA}

The scholarly, almost 'scientific' authority that Frontinus establishes around himself at the start of the Strategemata (and that is typical of many a military author) thus gives way to a very different kind of 'expertise' over the course of the text (one often celebrated in more historical texts) - if the innate 'cleverness' of lots of different generals can indeed be called 'expertise'. In fact, that is one of the questions which

${ }^{22}$ Strat. 1.4.12 and 3.15.4; also, e.g., Strat. 3.13.3-5, although these exempla may be later interpolations.

${ }^{23}$ E.g., Strat. 4.1.18, 20, 24, 25, 28, 38.

${ }^{24}$ Pyrrhus' Art of War is mentioned by Cicero (Ad. Fam. 9.25.1) and Polyaenus (6.6.3).

${ }^{25}$ Strat. 1.1.1; 1.4.13; cf 3.1.7-8. Cf. Vegetius, Epitoma 3.10.17-18 (discussed by Formisano in this volume).

${ }^{26}$ By contrast, exemplary figures in Valerius Maximus are sometimes described as imitating or learning from other exemplary material (Langlands 2008: 163, n. 14). 
the Strategemata raises. What does 'expertise' in the strategic context consist of - a high degree of prescribed, specialist knowledge, or a less disciplined, less fathomable and less acquirable kind of skill? Does the text endorse the shared authority of the scholarly tradition to which it claims to belong? Does it give more weight to a more solitary, intuitive kind of 'know-how' that does not arise out of that tradition? Or does it champion both - or neither? To put it another way, how do the text's different authority figures - its erudite, systematising author and the hundreds of adroit but by and large unlearned generals to whom he entrusts the task of instructing his readers relate to each other? Do the different models of expertise and authority that they embody work in partnership, in parallel, or in tension with one another? ${ }^{27}$

Cleverness and cunning were identified as a crucial feature of successful generalship from Homer onwards, of course. Indeed, the 'wiles' of Odysseus have long been shorthand for the whole of the more cerebral side of war, the antithesis of plain might or simple valour. And many texts testify to a widespread assumption in Roman society in particular that generalship was more a matter of practice, character and innate ability (as well as social status) than scholarship or science. (It is that kind of assumption that Rycharde Morysine is also arguing against in the preface to his sixteenth century translation of the Strategemata quoted above.) In the pro Fonteio, for instance, Cicero hails the generals of former days (who represent an ideal whom today's lesser men would do well to emulate) for their virtus ('valour'), industria ('energy') and felicitas ('good fortune') in military matters, and states outright that these men, highly skilled in waging war, were not trained in any military science that came from books (non litteris homines ad rei militari scientiam...) but by their own deeds and successes (sed rebus gestis ac victoriis eruditos). ${ }^{28}$ Similarly, when celebrating Pompey's extraordinary military prowess in his speech On Pompey's Command, Cicero emphasises not only its practical (as opposed to theoretical) foundation (going into the army straight from school, Pompey could boast more encounters with the enemy than any other man; indeed, he had conducted more campaigns than other men have read of) but also its basis in that more elusive phenomenon, ability - and its natural consequence, success: 'as a young man he became learned (erudita) in the science of war (ad scientiam rei militaris) not through other men's prescriptions but through his own commands, not through the set-backs of battle but through victories, not through mere service but through triumphs. ${ }^{29}$

That is not the whole picture, of course; it was widely recognised that most generals acquired at least some of their know-how from sources external to their own experience. In Epistles 8.14.4-5, Pliny the Younger (a contemporary of Frontinus) looks nostalgically back to the time when it was the established custom for aspiring young commanders to learn from their elders (a practice now problematized, he claims, by the lack of virtus in all generations under Domitian): 'It used to be the custom in days gone by that we would learn from infancy upwards from our elders, not only by listening but also by watching, and so acquire a sense of the things that we ourselves must do and pass them on in turn to our juniors. Thus young men were initiated into military service right away, so that they might get used to commanding

\footnotetext{
${ }^{27} \mathrm{Cf}$. Formisano in this volume, who identifies the tension between theory and practice as a recurring feature of the discourse of war, and one that has a habit of destabilizing the authority of texts.

${ }^{28}$ Pro Fonteio 42-3. On this and some of the following passages, see Campbell 1987: 21-3.

${ }^{29}$ De Imp. Cn. Pomp. 28. See also, e.g. Pro Balbo 47, where Cicero implicitly contrasts' Gaius Marius' military know-how with a more theoretical kind of study; and Sall. Jug. 85 (discussed by Formisano in this volume).
} 
by obeying, and to leading by following., ${ }^{30}$ In Tacitus' Agricola (5), we see Agricola himself acquiring skill (ars), practice (usus) and ambition (stimulus) not only through his own early hands-on experiences but also by 'learning from the skilful, and following the best'. And Cicero praises another general, Lucullus, not only for his 'talents' but also for his 'industry' and 'enthusiasm', which led him - when posted to Asia to campaign against Mithridates - to spend the whole of his journey there 'questioning experts on the one hand and reading about past deeds on the other'. 'Thus he arrived in Asia as a finished commander, despite having been unversed in military matters when he set out. ${ }^{31}$ The potential of book-learning was acknowledged, in other words, alongside other instructive forces. Indeed, if Vegetius is to be believed, that was the impetus behind Cato's (practically inspired) De Re Militari.

The reading that Lucullus does (like Cato's writing) is essentially an extension of the oral tradition that Pliny romanticises - the kind of book-learning associated with historical texts and the exempla tradition (and with the education of the young by their seniors), not with theoretical or scientific works. ${ }^{32}$ Other authors promote the relevance of more specialist, systematising, even 'technical' texts, however; in fact it is clear that, although innate ability and practice were highly valued, they were often seen as something that could be combined with more formal learning. In a devastating critique of some Achaean generals, for instance, Polybius famously argues that 'There are three routes available to those who want to acquire an understanding of the art of generalship: the first is the study of memoirs and the campaigns narrated in them; the second is the study of the systematic doctrines of experienced men; and the third is personal experience and practice. (The Achaean generals, he claims, were ignorant of all three. ${ }^{33}$ ) Xenophon's earlier (mid-fourth century) Discourse on the Command of Cavalry certainly flirts with the idea that a military commander might learn his trade at least in part by following prescriptions set down in a treatise by an expert; although, at the same time as propounding some universal principles and even a degree of technical expertise, the text acknowledges the limitations of books and the relevance of both experience and ingenuity. ${ }^{34}$ At about the same time, in his only surviving treatise, How to Survive under Siege, Aeneas Tacticus weaves exempla together with a more 'scientific' approach by inviting readers to contemplate past practice (via lots of illustrative anecdotes) at the same time as establishing a canon of definitive methodologies and directing them to other treatises that he has written (e.g., 7.4; 8.2$5 ; 21.1-2)$.

From early on in the Greek military writing tradition, in other words, 'scientific' learning, experience and nous were brought into (a shifting) dialogue with each other; and that trend was not restricted to ancient Greece. In the tenth book of Vitruvius' treatise On Architecture, for example, a series of architects and engineers outwit various military commanders and win decisive victories for their own generals and countrymen by employing a mixture of scientia (precisely the kind of specialist, technical knowledge that Book 10 claims to transmit) and sollertia and consilia

\footnotetext{
${ }^{30}$ Pliny is romanticising the transmission of what might be termed 'tacit knowledge', 'things that cannot be articulated in a written form, and whose transmission requires socialisation with the expert, or with the expert community' (Cuomo 2011: 327); this is different from the kind of intuitive, inborn 'cleverness' that the Strategemata's generals tend to display.

${ }_{31}$ Cicero, Lucullus 1.1-2.

${ }^{32}$ On the likelihood that Cato's military writing was part of his set of instructions destined for the education of his son, see Lenoir 1996: 84; also Astin 1978: 184-5.

33 Polybius 11.8.1-2.

${ }^{34}$ See esp. the treatise's closing section, 9.1-2; also 8.1-3, on technical expertise; 5.4, on experience; 5.1-3, 5.9-11, and 7.1, on ingenuity and ruses; cf. Memorabilia 3.3.
} 
(native cunning and shrewd judgement). ${ }^{35}$ As Serafina Cuomo has pointed out, when Vitruvius was writing the question 'what makes a good military leader?' (birth, virtue, experience, or/and specialized knowledge?) had become particularly urgent, following a rise in the prevalence and importance of technical expertise in recent conflicts, and we can see authors like Caesar grappling with it too. ${ }^{36}$ Eighty years later, the ideal general that emerges from Onasander's Strategikos also represents a finelytuned balance of native qualities and acquired expertise. This text opens with a particularly forthright exposition of the principle that successful generalship depends at least in part on character (Strategikos 1-3). It returns time and again to the importance of both cleverness, intelligence ( $\alpha \gamma \chi \downarrow v o i \alpha, \gamma v \omega \dot{\mu} \mu)$ and experience ( $\left.\dot{\varepsilon} \mu \pi \varepsilon \imath \rho^{\prime} \alpha\right) .{ }^{37}$ But it also toys with the possibility that collective strategic wisdom can be usefully systematised and handed on as a 'science'; indeed, it attempts to distil from past practice ( $\sigma \tau \rho \alpha \tau \eta \gamma \eta \mu \alpha \tau \alpha$ - illustrative 'strategems') an overarching 'theory of generalship' ( $\sigma \tau \rho \alpha \tau \eta \gamma \imath \kappa \tilde{\eta} \varsigma \delta \dot{\varepsilon} \pi \varepsilon \rho i ̀ ~ \theta \varepsilon \omega \rho i ́ \alpha)$ that aims 'to get at the art of the general and the wisdom that inheres in the precepts' (Strat. pr. 3). ${ }^{38}$ Time and again, in other words, ancient texts (and many subsequent ones too, for that matter) present generalship as an endeavour that operates somewhere between sollertia and scientia. As the appeal of systematisation and rules competes with (or asserts itself into) the complex reality of warfare, native wit, collective experience and more scholarly approaches are seen to complement - and even be indispensible to - each other. ${ }^{39}$

\section{UNPICKING THEORIES IN STRATEGEMATA 1-3}

In theory, Frontinus' Strategemata fits into and perpetuates that trend. Frontinus had almost certainly read and may well have been influenced by the likes of Xenophon, Aeneas Tacticus, Polybius, Vitruvius and Onasander, inter alia. Of course, we can only guess at the format and contents of his earlier De Re Militari; but his collection of 'clever deeds of generals', designed as it was (or so we are told) to supplement that earlier scientia, ought by its own reckoning to sustain the collaboration that other authors had long been mooting between unlearned strategic know-how/experience and more specialist, disciplined, 'scientific' learning. Perhaps the two texts did complement each other, in all sorts of ways that we will never know about. Even if they did, however, there is no getting away from the fact that some aspects of the Strategemata work against, in real tension with, the momentum of more systematising, 'scientific' endeavours. In fact, in distilling sollertia ducum facta from both historical and more 'technical' sources and in rearranging them together (stripped of their contexts) into a new textual space, the Strategemata potentially unpicks the efforts of a huge range of texts - both scientific and un-scientific - to theorise and idealise about generalship. It raises questions about the authority of wider literary and

${ }^{35}$ De Arch.10.16, where one of the generals outwitted by this combination of scientia and sollertia is none other than Julius Caesar (König 2009: 49-50).

${ }^{36}$ Cuomo 2011: 323-6; on the increasing importance of technical skill, see also Cuomo 2007: 73.

${ }^{37}$ E.g., Strategikos Pr. 7; 21.3-4; 24; 32.9; 33; 42.10.

${ }^{38}$ On Onasander's text, see esp. Formisano in this volume.

${ }^{39}$ Even Aelian's highly technical Tactical Theory recommends combining precepts with practice (Tact. 21.2-3); see also 3.4, where he distinguishes between the 'science' set down by Aeneas Tacticus and the more hands-on kind of training (paideia) that Polybius appears to advocate. Formisano 2009: 228-30 offers a particularly succinct survey of ancient military writing, and its oscillation between technical theories and evocative exempla. 
intellectual traditions (like historiography and epic), in other words, not just military writing. And in the process, it challenges assumptions about the provenance, nature and status of individuals' strategic expertise and authority. ${ }^{40}$

For, for all its superficial organisation, a destabilising sense of chaos emerges as one reads the Strategemata through. As I noted above, the text's classification of exempla according to the various stages of conflict that a general might face makes an authoritative, rationalising impression. However, this organisation of material does not simply place like stories alongside each other in ways that illuminate particular strategic themes; it also juxtaposes anecdotes in various disorientating ways. ${ }^{41}$ For instance, we repeatedly see stratagems that proved successful in one encounter being overturned (or adapted and turned back on the enemy) a few exempla later. Similarly, victorious generals are frequently defeated by others in turn - sometimes by the very foe we had just seen them vanquish. This emerges particularly clearly in Frontinus' presentation of Punic exempla: Scipio, Hannibal and a host of other Roman and Carthaginian commanders are frequently seen foiling or adapting each others' stratagems in quick succession, in a disconcerting back-and-forth between victory and defeat. No matter how much know-how or sollertia they have at their finger-tips, the 'heroes' of the text are always on the verge of being outmanoeuvred themselves, with luck often playing a part. It is not simply that reliable patterns and methodologies fail to emerge (and are even undermined) as one reads each section through; the anecdotes are interspersed with each other in ways which underline the profound unpredictability and uncontrollability of warfare. In the to-and-fro of battle (that emerges so powerfully from the to-ing and fro-ing each section does between Roman, Carthaginian, Spartan, Athenian, Sullan, Sertorian, Pompeian and Caesarian victories) even experience and on-the-spot ingenuity sometimes count for nothing - or emerge, at least, as having only ephemeral effects. Expertise of all kinds proves far from infallible, while generalship (it becomes clear) involves a good deal of chance. ${ }^{42}$

That message has obvious ramifications for a host of military treatises, particularly those with strong rationalising tendencies (many of which have a tendency to downplay the significance of chance and the unpredictability of warfare); but the internal dynamics of the Strategemata pose a challenge to other literary traditions too. The text's constant back-and-forth between different time-periods dismantles familiar historical narratives, for instance. Exempla from Rome's various conflicts with Carthage, for example, are scattered all over the text, with episodes from the first, second and third Punic wars even merging into each other in ways that frustrate attempts to identify progress, decline or any kind of periodization. Material that readers would normally encounter in historical works (as Frontinus himself points out in his introduction) is rearranged a-chronologically, according to military time what happens when in a battle - in a way that foils many of the conventional and ideological interpretative moves readers are accustomed to make when trying to assess it. That is destabilising in a general way, but particularly so because such

${ }^{40}$ The arguments that follow are explored at greater length (and with more detailed discussion of illustrative passages of text) in my forthcoming book on Frontinus. They have something in common with Kronenberg's approach in this volume to Varro's $A R D$, in their openness to the possibility that Frontinus (like Varro) may be exposing to scrutiny - if not satirizing, precisely - some of the literary and scholarly traditions that his Strategemata supposedly derives from and contributes to.

${ }^{41}$ On the tendency of readers to search for order, coherence, themes and subtexts even in miscellanistic writing, see J. König 2007.

${ }^{42}$ Of course, Frontinus is not alone in acknowledging the role played by chance in and the unpredictability of - warfare; the Strategemata is unusual, however, in foregrounding both so prominently. 
historical texts served both as an alternative and a complement to more technical military treatises. Thus both traditional sources of strategic instruction and inspiration - the historiographic and the scientific - are being challenged here.

Even more disconcerting is the text's failure to observe or preserve geographical, ethnic or cultural divisions. Many of the surviving military treatises that set out to explore or establish enduring military principles, especially those written under the Roman empire, combine that universalising project with one that asserts the distinctiveness of different nations. Onasander's Strategikos, for instance, invites readers to reflect on Roman (in comparison with non-Roman) military models; ${ }^{43}$ and Frontinus' near-contemporaries Aelianus Tacticus and Arrian (in his Ars Tactica, for example) both differentiate between Greek and Roman military methods (in different ways, and with different agenda). ${ }^{44}$ Of course, ethnic and cultural differences are a recurring (indeed, often a structuring) topos in ancient historiography too; in fact, questions about national identity (and the desire to define it) informed the composition and consumption of many ancient texts in a huge variety of genres. ${ }^{45}$ Valerius Maximus' decision to distinguish between his Roman and non-Roman exempla, in other words, would have seemed more conventional to ancient readers than Frontinus' decision not to. For as well as jumping here, there and everywhere chronologically, Frontinus' exempla are organised in a way that criss-crosses all over the Greek and Roman worlds. From time to time Frontinus identifies with Roman forces, referring to them as nos, or nostri; but the text does not promote national ideals or support Romano-centric historiography in the way that many others do. ${ }^{46}$ Plenty of Roman stratagems arouse admiration, of course, and we see the borders of the empire being extended and defended. However, the to-and-fro of the text means that linear narratives of conquest and expansion give way to a more complex kaleidoscope of images that emphasises the frequent back and forth and convoluted inter-relations between Romans, Italians and other allies or subjects. Additionally, interspersed with exempla from inter-state conflicts is a significant number of anecdotes from Rome's various civil wars - another way in which Frontinus' text differs from that of Valerius Maximus, who explicitly eschews reference to civil strife (3.3.2).

Many of the macro-narratives that we are familiar with about Athens, Sparta, Persia, Thebes, Macedon, and so on, are similarly broken up by the text's constant oscillation (within individual sections and across the collection as a whole) between different theatres of war; and also by the way in which that oscillation underlines the multi-national dimension of many conflicts (and nations' histories). We repeatedly see Spartans, Gauls, Macedonians, Iberians and so on fighting on different fronts, with different allies and enemies, in exempla that are juxtaposed with each other. And

${ }^{43}$ Strat. pr. 3-4, where he claims that 'we shall consider above all the valour of the Romans'. Cf. Ambaglio 1981: 362-5, who argues that Onasander promotes specifically Greek principles and exempla to his Roman readers in order to establish the ongoing significance of Greece in Rome; and Formisano 2011: 45, who notes the lack of references to Roman history.

${ }^{44}$ Stadter 1978: 41-5; Bosworth (1993).

${ }^{45}$ As Harries notes in this volume, an emphasis on the Greekness or Romanness of a particular body of knowledge was often deployed in specialist texts to enhance the authority of the expertise they promised to share.

${ }^{46}$ Cf., e.g., Valerius Maximus (2.7.pref.), who identifies military discipline as largely the prerogative of his own race, 'the chief glory and mainstay of the Roman empire' no less. Overall Roman exempla slightly out-number non-Roman ones (see Campbell 1987: 15, n.11 for the figures), but (as Gallia 2012: 197, n. 56 points out) '...the clever stratagems of Roman generals make up only 56 percent of the total.' 
the parallels and paradoxes that emerge from these jumps and juxtapositions, as different histories are brought into proximity with each other, expose history itself as a bewildering tangle of unpredictable oscillations between different peoples. In excerpting episodes from a huge variety of texts, in other words, and in rearranging them alongside other thematically related anecdotes from different times and places, the Strategemata does not simply criss-cross but somehow erodes (or exposes as inherently unstable) political and cultural boundaries. It teaches us that stratagems and successful generalship are not the preserve of one particular race more than any other; and in so doing, it also unpicks many other stories that are conventionally told about the Mediterranean past, obscuring rather than reinforcing a host of ideas that have built up about national distinctions and identities. Thus it is not simply histories that are deconstructed here; fundamental aspects of foundation myths and national ideologies - the stuff of epic even - have their authority challenged; some of the very narratives, indeed, that often contribute to the construction of an individual general's or nation's strategic authority.

This may not be intentional; indeed, it is (in part, at least) an inevitable consequence of the excerpting process, what often happens when material is lifted from lots of different sources and arranged together according to new criteria (although Valerius Maximus offers a telling counter-example of a compilatory text that operates rather differently, as does Polyaenus' later Strategemata, which groups stratagems chronologically and geographically). Even so, the effect is disorienting as is Frontinus' authorial absence. There are a few rare occasions when Frontinus slips in the odd word of personal analysis. He might note that a stratagem was carried out ita perite ('with such skill'), for instance (3.13.6), or he might identify a general's 'steadfastness' or the 'imprudence' of certain troops as significant (e.g., 2.7.11 and 12, where we see the ghost of some authorial interpretation). For the most part however, he almost never intrudes to offer any guiding commentary - despite his own significant strategic experience, reference to which would have lent his voice extra authority. While Valerius Maximus' regular expressions of approbation, condemnation, exclamation and exhortation steer his readers towards particular interpretations, Frontinus suppresses the author's analytical, expert potential, leaving his material to speak for itself and his readers to identify what connections or themes they will. ${ }^{47}$

Of course, much of Valerius Maximus' assertive interpretation is focused around his interest in exploring right and wrong, virtue and vice. Ethics are foregrounded in Onasander's Strategikos, too, as something that should guide a general in his military decisions and activities (and lend him a different kind of authority alongside his strategic expertise). In fact, many ancient discussions of warfare and generalship touch on ethical issues, be they historical, philosophical or more 'technical' accounts. ${ }^{48}$ Though many before him had acknowledged that stratagems especially were often morally debatable, ${ }^{49}$ this is not an angle we are encouraged to pursue in Frontinus' Strategemata, however. Unlike Valerius, Frontinus tends to avoid morally emotive vocabulary like dolus (trick), fallacia

\footnotetext{
${ }^{47}$ As Langlands 2008: 162, n.10 notes, authorial comment does not necessarily limit the potential multi-valence of exempla; lack of authorial comment, on the other hand, further enhances their 'undecidability' (Lyons 1989: 8-15).

${ }^{48}$ E.g., Thuc. 1.71-9 and 3.36-49; Plato, Alcibiades 1, 107c-109d; Plato Rep. 5.470c1c; Plato, Laws 1.628c-e; Aristotle, Nichomachean Ethics 3.5-9 (1115a3-17b23); Aristotle Politics 7.2 (1324b2-5a10); Polybius 18.14-15 and 35-7; Cicero De Off. 1.34-41 and 61-68; Virgil, Aen. 12.919-52. See also Most 2011 on justice and war in Hesiod.

${ }^{49}$ Esp. Val. Max. 7.4; cf. Wheeler 1998: 2-18; 21; 109.
} 
(deceit) and vafritias (craftiness), preferring the more intellectual language of consilium or ratio even above words like sollertia and calliditas when describing the thought-processes of his generals. His lack authorial commentary also means that accounts of the clever use of terrain or the deft way in which a lack of resources was overcome are narrated with the same compressed neutrality as, for instance, an episode in which Roman soldiers are induced to gorge on raw meet so that they may be attacked later that night while struggling to digest it $(2.5 .13) .{ }^{50}$ Very occasionally a character from within an anecdote questions the ethics of a commander's behaviour (at 3.12.2, 3.11.1 and 2.5.41, for instance); however, rather than pursuing or endorsing their protest, the text focuses on (and holds up for approbation) the end result of the stratagem, not its morality. ${ }^{51}$ Ethics are thus subordinated to tactics, as virtuous and unscrupulous commanders triumph alike. Of course, this is the reality of many a history; but in the case of the Strategemata, which presents these exempla as authoritative models for readers to imitate, it may be a little more disconcerting - not least because they would be used to, or aware of, other military manuals that are more ethically judgemental or prescriptive. It is not simply that ethics are overlooked or subordinated, in other words; readers of the Strategemata are invited to contemplate acting unethically from time to time themselves (that is, to dispense with some of the moral parameters that, in dialogue with other social, cultural and political discourses, often boosted a general's wider authority, at least in retrospect), as the text prompts them to visualise themselves not just as another Alexander, or another Scipio, or Cato, but as another Tarquinius Superbus, or another Iphicrates, or Coriolanus. ${ }^{52}$ More than that, they are (once again) prompted to reflect on the habits and validity of historiographic traditions that have long been valued for their didactic potential.

The variety of people whom the Strategemata suggests readers might emulate is potentially disconcerting in other ways too. No distinctions are drawn between kings and slaves, consuls and rebels, emperors and bandits, magistrates and mercenaries, and in a couple of exempla women show themselves as capable as men when it comes to devising stratagems. Perhaps more significantly, non-experts and one-day-wonders triumph alongside experienced or virtuoso generals, and occasionally even overthrow them. This macro-trend brings us back to the impression that emerges out of individual exempla: that learning and training are less likely to determine a commander's chance of success than the wits he was born with and his on-the-spot 'cleverness'. But as the present section has shown, that impression is only one of the ways in which the Stratagemata undermines the authority of some of the more systematising, theorising, idealising texts and literary traditions that touch on warfare or generalship and shape ideas about what it is that can make a general seem particularly authoritative (in his own day, and beyond it). For en masse, and through their organisation and presentation as well as their selection, Frontinus' exempla unpick historical, epic and philosophical narratives about political periods, national identities and behavioural boundaries that so often feed into (and are in turn sometimes influenced by) the narrower literary-theoretical tradition that the

${ }^{50}$ Compare also Valerius Maximus' criticism of Carthaginian deceit (at, e.g., 7.4.ext.2) with Frontinus' authorial detachment at 2.2.7 (where Hannibal's positioning of his troops so that the Romans are troubled by wind and dust, far from being deplored, is set alongside exempla in which Romans and Thebans deploy the same trick - 2.2.8 and 12 - undermining the distinction that Valerius tries to draw between Roman and non-Roman behaviour).

${ }^{51}$ See also e.g. 2.11.5-7; and Wood 1967: 247 on this feature.

${ }^{52}$ Le Saux 2004: 99 notes earlier readers' anxiety about this feature of the Strategemata; cf. Livy (1 pref. 10) and Valerius Maximus, who present exempla for both imitation and avoidance. 
Strategemata claims to be part of: the 'drawing up' of a transferable 'science' of generalship. All strands of military writing (not just the technical tradition) are exposed to scrutiny here.

\section{FROM READING TO DOING}

As Marco Formisano has pointed out, we do not need to wait until the nineteenth century to find examples of military treatises that reflect as much on the 'essence' of war as they do on how to wage it; indeed, a number of ancient texts could be said to fall into that category. ${ }^{53}$ The Strategemata, I suggest, is one of them: whether intentionally or not, its collation and presentation of strategic exempla across all four books teaches us as much about the chaotic nature of battle as what stratagems or strategy a general might adopt to try to control it. ${ }^{54}$ In so doing, however, it also prompts reflection on some of the wider literary movements that it draws on and engages with - especially the systematising, 'scientific' side of the military writing tradition. Through the military precision of their internal organisation, Books 1-3 appear to distil history into a comprehensive set of instructive illustrations for every strategic eventuality. And yet the volume, variety and disorienting to-andfro of the exempla within each sub-section combines with an emphasis on on-the-spot intuition, intelligence and native wisdom (rather than learning, training or experience) to frustrate attempts that we might make to relate them to - let alone derive from them - any coherent, definitive, idealising or self-promoting theory of tactics or generalship. Then Book 4 is tacked on, and sections 4.1-6 - which organise their exempla into moral categories such as 'On Discipline', 'On Justice' and 'On Steadfastness' - try out a different methodological approach that brings us closer to a more prescriptive, theorising (and indeed ethically-oriented) kind of treatise, at the same time as moving us further away from the idea that such a treatise could ever be conclusive or completely convincing. (Book 4, after all, is presented as a supplementary afterthought to an already supplementary text, part of an on-going expansion of Frontinus' original literary project. ${ }^{55}$ ). Finally, section 4.7 (de variis consiliis) steers us away from virtues and back to 'sundry' examples of consilium (Frontinus' favourite synonym for sollertia, strategic 'cleverness' or 'cunning'). Intuition, intelligence and native wisdom (those potent but elusive qualities) take centre stage again, but in a miscellany of exempla that return us to many of the themes treated in Books 1-3 and emphasises more than ever the bewilderingly infinite array of situations that any general may face, and the near impossibility of employing even well-established strategic approaches in predictable ways. ${ }^{56}$

\footnotetext{
${ }^{53}$ Formisano 2011: 40-1.

${ }^{54}$ The authorship of Strat. 4 was questioned in the nineteenth century (Wachsmuth 1860; Wölfflin 1875); but Bendz 1938 argued in favour of identifying Frontinus as its author, and has since been followed by the majority of commentators (e.g., Goodyear 1982; Campbell 1987: 15; Wheeler 1988: 20; Campbell \& Purcell 1996: 785; Turner 2007: 432; Gallia 2012: 204; Malloch 2015).

${ }^{55}$ Strat. 4 pr. distinguishes between Book 4 and the rest of the treatise, and stresses the potential incompleteness of the author's efforts: '...I shall now set out in this book examples that did not seem to come under quite the same category as those in the earlier books..., namely examples rather of generalship than stratagems - as a way of completing the project of the three earlier books (if indeed I have completed them).' ${ }^{56}$ In this breakdown of categories and textual organisation, Frontinus may even be satirizing attempts by other writers to systematize military know-how successfully.
} 
The very last exemplum in the book encapsulates that lesson in unpredictability beautifully. Quintus Metellus, the 'hero' of the tale, is in Spain, about to break camp; and in order to keep his troops in line, he deceives them, telling them that he has discovered that ambushes have been laid by the enemy. We are told that he did this ex disciplina - 'to maintain discipline'; but, by chance (forte), they then did meet with an ambush, and because the soldiers were prepared for one they were unafraid. In being unexpectedly providential, Metellus' approach advocates the strategic advantages of disciplina (something often promoted in technical, historical, ethical and epic descriptions of generalship); but it also reminds readers of the accidental, unforeseeable, uncontrollable forces of war, and of the chance that is involved in strategic success (or failure). In that sense, 4.7 .42 offers a compelling conclusion to the Strategemata, in so far as it alerts readers one final time to a message that the entire collection has been building towards (right from Frontinus' very first preface): that, no matter how many supplementary bits are added, no text, not even one as expansive as the Strategemata, can hope to offer complete closure on or be definitively authoritative about tactics or generalship, because in war the unexpected will always happen. ${ }^{57}$ As well as completing and complementing his earlier scientia rei militaris, in other words (for instance, by reinforcing disciplina as a principle), this vast and destabilising collection of sollertia ducum facta threatens to undermine it - and the authority of many other prescriptive, theorising, idealising or romanticising discussions of generalship and warfare - by making it clear how many endless permutations of strategic cleverness there are (and must be) because war itself presents an infinite variety of challenges. ${ }^{58}$

That is not to say that the Strategemata does not teach its readers how to think up stratagems or operate as a general. (In arguing this, I should stress, I am not suggesting that the Strategemata's readers were all or exclusively interested in learning the hands-on practicalities of generalship. Many would have been reading with broader intellectual agenda - to inquire into the nature of military strategy, perhaps, or the history of generalship. Because the text casts all of its readers in the role of aspiring generals, however, we are all invited to consider what practical lessons we potentially learn from it, whatever our other agenda.) In fact, it is profoundly instructive even as it exposes its own limitations and those of the wider military writing tradition - precisely because it confronts readers with the fact that they can never hope to acquire an exhaustive set of easy-to-implement prescriptions and forces them into a different model of learning from the one that so many other texts default to (whereby an expert passes on general precepts to the uninitiated). At first glance, it might look as if Frontinus establishes a very simple relationship between his text (and the know-how that it embodies) and his readers (and the knowhow that they supposedly aspire to): one that sets the Strategemata up as a direct conduit of strategic expertise between former and future commanders and implies a single step between reading about successful stratagems and performing some oneself. ${ }^{59}$ The language that he uses, however, to characterise that relationship in the preface to Book 1 reveals that it is rather more complex than that, and that reading does not necessarily translate immediately or straightforwardly into an ability to do. This is what he says, after he has explained his reasons for writing the Strategemata:

\footnotetext{
${ }^{57}$ Smith 1998: 163, n. 52 is thus wrong to suggest that Book 4 'tails off limply'. ${ }^{58}$ This takes one step further a disclaimer often made in 'technical', 'scientific' or encyclopaedic texts, that they cannot hope to be fully comprehensive. Cf. Doody's suggestion in this volume that Varro's De Re Rustica is another text which questions the authority/efficacy of writing when it comes to learning about agriculture.

${ }^{59}$ This is how many read it; e.g. Gallia 2012: 193.
} 
'Future generals will thus be surrounded [or 'girded up' - succincti] by examples of wisdom and foresight, which will nurture (nutriatur) their own ability to think up (excogitandi) and generate (generandi) 'similar deeds' (similia). It will also follow that a general need not be nervous about the outcome of his own inventiveness (inventionis suae), because he will be able to compare it with experiments that have already been tried out.' (Strat. 1. pr.1)

This is explicitly nourishing, supportive language - indeed, the kind of language that might characterise a commander's relationship to his troops, for succingo can be used for 'equipping' an army. On one level, then, Frontinus as author (or commander in chief) is supplying his readers (or generals) with the 'equipment' they need to succeed as military leaders. However, the emphasis on 'thinking up', 'generating' and 'inventiveness' also puts the onus on them not merely to copy but to come up with similarly successful stratagems of their own devising - and that inserts another, far more challenging step into the process. It is not simply a case of taking up the proffered 'equipment' that the text offers, in other words, and putting it into practice. The Strategemata demands something more from aspiring generals/readers, something whose difficulty (as we have seen) the text itself underlines. For, although the vast litany of 'clever' commanders that the Strategemata parades before our eyes reminds us that a huge variety of people in the past have been successful strategists and dangles the prospect of further 'like deeds' (similia) tantalisingly in front of us its emphasis on the role played by both chance and native, on-the-spot, unlearned 'cleverness' makes the likelihood of achieving any comparable strategic triumphs of our own look dauntingly remote, even with a handbook to 'help' us.

We need not despair, however. The verb succingo can mean to 'hem in', or even 'besiege', of course, as well as to 'surround' or 'equip', and that is fitting because in a sense that is what the Strategemata does to its reader. It transports us to lots of tricky battlefield scenarios, and instead of offering us hard-and-fast rules it encircles (one might almost say ambushes) us again and again with an array of strategic exempla that undercut many of our assumptions about the foundations of generalship. And yet that process is itself didactic in quite a sophisticated way: for instead of offering us prescriptions in the manner of many 'technical' treatises, Frontinus gives his readers an experience of the on-the-spot processes of decisionmaking in unpredictable circumstances that a successful general needs to be expert in. In plunging us into these situations (which take us steadily through the different stages of battle) and surrounding us with so many different (and differently valid, sometimes controversial) strategic options, the text gives us the opportunity to hone our skills of generalship (or observe the nature of it) - to confront the difficulty of decision-making and to practice exercising our judgement, drawing on our nous and being inventive in conditions which are constantly shifting - rather than just offering a set of exempla that can be straightforwardly imitated. ${ }^{60}$ That is similar to the way in which Rebecca Langlands has suggested Valerius Maximus' collection teaches us ethics; ${ }^{61}$ but it also takes us back to a long-established and much romanticised nontextual tradition of learning about generalship that I mentioned above, the kind that

${ }^{60}$ Cf. Wood 1967: 246-8.

${ }^{61}$ On this, see esp. Langlands 2008, who draws attention to the interaction between strings of exempla in Valerius Maximus (which expose ethical complexity, not clarity) and argues (160) that Valerius' arrangement of ethical exempla 'is designed to tell Roman readers not simply what to think but how to think ethically, enabling Roman readers both to explore the scope of these moral categories and to develop their skills of moral reasoning.' See also Langlands 2011: 23; J. König 2007 on Plutarch's Sympotic Questions; and Rimell 2007 on Petronius' Satyricon. 
Cicero talks about in his text On Pompey's Command, where commanders learn about generalship by commanding (victoriously).

The Strategemata, then, is not so much a nourishing as a challenging text but that is what makes it instructive, in all sorts of respects. As we have seen, it brings different manifestations of 'expertise' (systematising, 'scientific' authors, and intuitive, unlearned but triumphant former generals) not only into collaboration but into tension with each other. In so doing, it raises questions not just about what authorial and strategic expertise respectively consist of but also about the authority of a whole range of texts which depict generalship, both within and beyond the military writing tradition (historical, philosophical, and even epic, as well as 'technical' works). In fact, its overlaps and engagement with non-technical as well as more 'scientific' texts draw attention to the shifting identity of (especially Latin) military writing and to its lack of consistency as a genre. ${ }^{62}$ More than that, in exposing the limitations of all such texts (itself included) to communicate reliably or conclusively about the nature of generalship, it prompts reflection (not necessarily consciously) on the relationship between writing, reading and doing - on the interplay between texts and the world that they aim/claim to reflect and influence. The Strategemata draws attention to a gap, on the one hand, between words and deeds - between the Art of Generalship as an intellectual, textual discipline and the act of generalship as practical phenomenon. At the same time, however, the didactic method that it adopts (that is reminiscent of some non-textual approaches to teaching and/or learning) goes some way towards bridging that gap, by providing a textual space in which its readers may absorb and even practice the very skills that could enable their or others' future deeds to go down in history (books) as successful strategic exempla. A treatise that overturns assumptions about authorial expertise and textual authority, in other words, ultimately proves itself expert and authoritative in instructing its readers - on a number of different levels: practical, theoretical and ideological - in the elusive 'art' of generalship.

\section{AUTHORS, GENERALS AND EMPERORS}

The relationship between writing and doing brings us back one final time to the authorial persona that Frontinus adopts in the Strategemata, which is strikingly different from the one he employs in a later, Nervan treatise, the De Aquis. In that text, Frontinus is a dominant and indeed exemplary presence: from its preface, where he parades his proximity to the emperor Nerva; through catalogue after catalogue of facts and figures (in which autopsy and Frontinus' personal interventions are repeatedly flagged); to the closing section, where the weight of the expertise and authority that he has accrued over the course of the text (both through its preparation and its publication) gives him the power to adjudicate on the emperor's behalf, as his representative not just his right-hand-man. ${ }^{63}$ Doing and writing come together to reinforce each other in lots of ways in that treatise. In the Strategemata, by contrast, Frontinus absents himself from the bulk of the text, as we have seen, handing the limelight over to his vast collection of exemplary commanders and rarely intruding with any commentary of his own. Perhaps the most striking aspect of his authorial self-effacement is the fact that this experienced commander (whose text revolves around the didactic potential of experienced commanders) makes almost no reference

\footnotetext{
${ }^{62}$ Lenoir 1996: 85 and Formisano 2011: 42 both note a lack of continuity between the surviving Latin military treatises.

${ }^{63}$ König 2007.
} 
to his own experiences as a commander. ${ }^{64}$ For Frontinus was an actor not just an author in the military sphere (indeed, in addition to his involvement in at least one German campaign, Frontinus had served as Governor of Britain just before Agricola and succeeded in subduing parts of Wales during his tenureship ${ }^{65}$ ). In Book 4 we find one exemplum which discusses a campaign that Frontinus was involved in (4.3.14and that anecdote deserves a whole chapter to itself). Aside from that there is no clear reference anywhere else in the text to any stratagems for which Frontinus was responsible. This failure to refer to his own strategic experiences is surprising particularly because there was a widely held assumption in many strands of ancient technical and scientific writing, not least in the military writing tradition itself, that an author's personal experience could lend his writing an extra layer of authority. That, after all, is one of the things that makes Cato an authoritative military writer. ${ }^{66}$

Of course, Frontinus may have referred to his own military experiences more in his lost De Re Militari. But there may also be a number of social and political explanations for his failure to bring his practical expertise and 'scientific'/scholarly authority into greater dialogue with each other in the Strategemata. ${ }^{67}$ His textual selfpresentation may have been closely linked to his public status, for instance. It is perhaps no surprise that he promoted himself and his activities so boldly in the De Aquis, for by then he had become a triple consul and one of Rome's most influential statesmen; moreover, he was writing from the heart of - almost as a spokesman for the imperial government. When he wrote the Strategemata (under Domitian) he had a lower public profile and was writing in a private capacity; and the persona that he adopts in that text may have been crafted in part to be commensurate with that: modest (as far as hands-on experience went), to suit a relatively modest $\mathrm{CV}$. It was also the case, of course, that authors constructed and paraded authority and expertise somewhat differently under different emperors. Arguably, Frontinus' reticence in putting himself forward as an exemplum (not just a scholar) in the Domitianic text had something to do with the political context in which he was writing - just as his assertiveness in the De Aquis exploited the Nervan-Trajanic regime's supposedly more liberal atmosphere. ${ }^{68}$ The currency of doing/experience versus writing/learning - and the kind of authority that an author might derive from each - fluctuated in response to many factors.

By way of conclusion, it is worth considering the other side of that coin too: the ways in which textual images and ideas of authority and expertise shaped wider discourses. For Frontinus' presentation of generalship and interrogation of different kinds of authority and expertise within the Strategemata had implications, potentially, for Domitian and the principate itself, raising all sorts of questions about both. For instance, how did the Strategemata's characterisation of generalship as an activity that almost anyone could turn their hand to but also something that was tantalisingly difficult to guarantee any success in (because native wit and chance were of more significance than learning or virtue) fit - or conflict? - with Domitian's attempts to

${ }^{64} \mathrm{Cf}$. Varro in the De Re Rustica, who (according to Doody in this volume) steps back from claims he makes in the prefaces about the extent and authority of his practical experience/know-how. Cf. also the preface to Onasander's Strategikos (and Formisano in this volume), where the value of authorial experience is debated.

${ }^{65}$ Tac. Ag. 17.

${ }^{66}$ See also, e.g., Polybius 12.25g; and Marius' speech in Sallust, BJ 85.12. On the use of the first person (and indeed the second-person) in technical/scientific texts, see esp. Hine 2009; also Nutton 2009.

${ }^{67}$ This is a topic I pursue in my forthcoming book.

${ }^{68}$ Compare Turner 2007 and Malloch 2015 on the politics of Frontinus' selfpresentation in the Strategemata. 
inflate his own military expertise and so further cement his imperial authority? Might the unpredictable to-and-fro of victory between a host of Roman and non-Roman imperatores have reminded readers how unexpected, short-lived and unstable command could be, and how brutal the process was when it was challenged? (For Domitian and his contemporaries - whose memories of the conflicts and chaos of AD 68-9 would still have been fresh, and whose anxieties about the future were equally pressing - that would naturally have been a destabilising message, one reinforced perhaps by the volume of civil war exempla in the text.) And what might the text's rejection of authoritative (indeed authorising) epic teleologies and moral fundamentals have done to the image and authority of the Roman empire?

Such political questions are not the only ones we might ask; but it is fitting to end by gesturing towards the wider context in which the Strategemata was written. For constructions and expressions of expertise and authority within individual disciplines always intersect with constructions and expressions of expertise and authority in other spheres of activity (literary, cultural, social and political), in thought-provoking and sometimes challenging ways.

Allmand, C. (2009) 'A Roman Text on War: The Strategemata of Frontinus in the Middle Ages', in P. Coss \& C. Tyerman (eds) Soldiers, Nobles and Gentlemen. Essays in Honour of Maurice Keen, Boydell Press/Woodbridge: 153-68 (2011) The De Re Militari of Vegetius; the reception, transmission and legacy of a Roman text in the Middle Ages, Cambridge

Ambaglio, D. (1981) 'Il trattato "Sul Comandante" di Onasandro', Athenaeum n.s. 59: 353-77

d'Assigny, M. (1686), The stratagems of war, or, A collection of the most celebrated practices and wise sayings of the great generals in former ages written by Sextus Julius Frontinus, one of the Roman consuls; now English'd, (Eebo Editions, Proquest, 2010)

Astin, A.E. (1978) Cato the Censor, Oxford

Bendz, G. (1938), Die Echtheitsfrage des vierten Buches der Frontinischen Strategemata, Lund

Bosworth, A.B. (1993), 'Arrian and Rome: the minor works', $A N R W$ II 34.1: 253-64

Campbell, B. (1987) 'Teach yourself how to be a general', JRS 77: 13-29

Campbell, B, and N. Purcell (1996), 'Iulius Frontinus, Sextus', in The Oxford Classical Dictionary. 3rd ed.: 785.

Cuomo, S. (2011) 'Skills and Virtues in Vitruvius Book 10', in M. Formisano \& H. Böhme (eds) War in Words. Transformations of War from Antiquity to Clausewitz, Berlin: 309-332 (2007) Technology and Culture in Greek and Roman Antiquity, Cambridge.

Devine, A.M. (1989), 'Aelian's Manual of Hellenistic Military Tactics: a new translation from the Greek with an Introduction', The Ancient World 19: 31-9

Eck, W. (1982) 'Die Gestalt Frontinus in ihrer politischen and sozialen Umwelt', in Wasserversorgung im Antiken Rom, Vol I (Sextus Julius Frontinus, Curator Aquarum), ed. Frontinus-Gesellschaft, Munich

Forhan, K. (2002) The Political Theory of Christine de Pizan, Burlington, VT: Ashgate

Formisano, M. (2009) 'The Renaissance Tradition of the Ancient Art of War', in G. Beltramini (ed.), Andrea Palladio and the Architecture of Battle, Venice: 22639

(2011) 'The Strategikós of Onasander: taking military texts seriously', Technai: an international journal for ancient science and technology 2: 39-52 Gallia, A.B. (2012) Remembering the Roman Republic. Culture, Politics and History 
under the Principate, Cambridge

Gerson, J. Oeuvres Complètes, Vol 2; Introduction, texte et notes par P. Glorieux (1960), Paris

Goodyear, F. R. D. (1982), 'Technical Writing', in E.J. Kenney (ed.) The Cambridge History of Classical Literature, vol. 2: Latin Literature, Cambridge: 667-673

Hine, H. (2009) 'Subjectivity and Objectivity in Latin Scientific and Technical Literature', in L. Taub \& A. Doody (edd.), Authorial Voices in Greco-Roman Technical Writing, Trier: 13-30

König, A. (2007) 'Knowledge and Power in Frontinus' On Aqueducts', in J. König \& T. Whitmarsh (eds), Ordering Knowledge in the Roman Empire, Cambridge: $177-205$ (2009) 'From architect to imperator: Vitruvius and his addressee in the De Architectura', in L. Taub \& A. Doody (edd.), Authorial Voices in GrecoRoman Technical Writing, Trier: 31-52

König, J. (2007) 'Fragmentation and Coherence in Plutarch's Sympotic Questions', in J. König \& T. Whitmarsh (eds), Ordering Knowledge in the Roman Empire, Cambridge: $43-68$

Langlands, R. (2008) " "Reading for the moral" in Valerius Maximus: the case of severitas', The Cambridge Classical Journal 54: 160-87

(2011) 'Roman Exempla and Situation Ethics: Valerius Maximus and Cicero de Officiis', JRS 101: 1-23

Lenoir, M. (1996) 'La Littérature De Re Militari', in C. Nicolet (ed.) Les littératures techniques dans l'antiquité romaine. Fondation Hardt, Entretiens sur l'Antiquité classique 42, Geneva: 77-115

Lyons, J.D. (1989) Exemplum: the rhetoric of example in early modern France and Italy, Princeton

Niccolò Machiavelli, Art of War; translated, edited and with a commentary by Christopher Lynch (2003), Chicago

Nutton, V. (2009) 'Galen's authorial voice: a preliminary enquiry', in L. Taub \& A. Doody (edd.), Authorial Voices in Greco-Roman Technical Writing, Trier: 5362

Malloch, S.J.V. (2015) 'Frontinus and Domitian: the politics of the Strategemata', Chiron 45

Marino Sanudo Torsello, The Book of the Secrets of the Faithful of the Cross (Liber Secretorum Fidelium Crucis), trans. Peter Lock (2011), Ashgate

Martin, J. (1997) 'John of Salisbury's Manuscripts of Frontinus and Gellius', Journal of the Warburg and Courthauld Institutes 40: 1-26

Mazour-Matusevich, Y. \& Bejczy, I.P. (2007) 'Jean Gerson on Virtues and Princely Education', in I.P. Bejczy \& C.J. Nederman (eds) Princely Virtues in the Middle Ages 1200-1500, Turnhout: Brepols

Morysine, R. (1539), The strategemes, sleyghtes, and policies of warre, gathered together, by S. Julius Frontinus, and translated into Englyshe, by Rycharde Morysine (Ann Arbor, 2003)

Most, G. (2011) 'War and Justice in Hesiod', in M. Formisano \& H. Böhme (eds) War in Words. Transformations of War from Antiquity to Clausewitz, Berlin: 13-21

Nederman, C. (ed.) (1990) John of Salisbury: Policraticus. On the frivolities of courtiers and the footprints of philosophers, edited and translated by Cary J. Nederman, Cambridge

de Pizan, Christine, The Book of Deeds of Arms and of Chivalry; trans. S. Willard, ed. C.C. Willard (Pennsylvania, 1999)

Riggsby, A. (2007) 'Guides to the Wor(1)d', in J. König \& T. Whitmarsh (eds), Ordering Knowledge in the Roman Empire, Cambridge: 88-107 
Rimell, V. (2007) 'Petronius' lessons in learning - the hard way', in J. König \& T. Whitmarsh (eds), Ordering Knowledge in the Roman Empire, Cambridge: $108-132$

Rodgers, R.H. (2004) Frontinus. De Aquaeductu Urbis Romae. Cambridge

Salisbury, John of, Policraticus I-IV; ed. K.S.B. Keats-Rohan (1993), Corpus Christianorum Continuatio Medievalis 117, Brepols, 1993

Santini, C. (1992), 'Il prologo degli Strategemata di Sesto Giulio Frontino', in C. Santini \& N. Scivoletto (eds.), Prefazioni, Prologhi, Proemi di Opere TecnicoScientifiche Latine, Vol. II, Rome: 983-990

Sanudo Torsello, M., The Book of the Secrets of the Faithful of the Cross; Liber Secretorum Fidelium Crucis; trans. P. Lock (Ashgate, 2011)

le Saux, F. (2004) 'War and knighthood in Christine de Pizan's Livre des fait d'armes et de chevallerie', in C. Saunders, F. le Saux \& N. Thomas (eds), Writing War: Medieval Literary Responses to Warfare, Cambridge: 93-105

Smith, C.J. (1998) 'Onasander on How to be a General', in M. Austin, J. Harries \& C. Smith (eds), Modus Operandi: Essays in honour of Geoffrey Rickman, London: 151-66

Stadter, P. (1978), 'The Ars Tactica of Arrian: Tradition and Originality', Class. Phil. 73.2: $117-128$

Thomas, A. (1930) Jean Gerson et l'Education des Dauphins de France. Etude Critique, Paris

Turner, A. (2007) 'Frontinus and Domitian: Laus Principis in the Strategemata', Harvard Studies in Classical Philology 103: 423-49

Wachsmuth, C. (1860) "Ueber die Untichtheit des vierten Buches der Frontinischen Strategemata", RM 15:574-583

Wheeler, E.L. (1988) Stratagem and the Vocabulary of Military Trickery, Leiden

Willard, C.C. (1995) 'Pilfering Vegetius? Christine de Pizan's Fait d'Armes et de Chevalrie', in L. Smith \& J. Taylor (eds) Women, the Book and the Worldly, Selected Proceedings of the St Hilda's Conference, 1993, vol. 2, Cambridge: 31-7

Wood, N. (1967) 'Frontinus as a possible source for Machiavelli's method', Journal of the History of Ideas 28.2: 243-8 